\title{
Interaksi sosial guru dalam pembelajaran Pendidikan Kewarganegaraan di SMA Katolik Karitas
}

\author{
Theodorus Pangalila ${ }^{\text {a, }}$ * \\ ${ }^{a}$ Prodi PPKn FIS Universitas Negeri Manado, Manado, Indonesia \\ ${ }^{1}$ theopangalila@unima.ac.id* \\ *korespondensi penulis
}

\begin{tabular}{ll}
\hline \multicolumn{2}{l}{ Informasi Artikel } \\
\hline Sejarah artikel & \\
Diterima & $: 27-01-2019$ \\
Revisi & $: 31-03-2019$ \\
Dipublikasikan & $: 31-10-2019$ \\
\hline
\end{tabular}

Kata kunci:

Interaksi Sosial

Guru

Pembelajaran PKn

\begin{abstract}
ABSTRAK
Penelitian ini bertujuan untuk mendeskripsikan interaksi sosial Guru dalam pembelajaran Pendidikan Kewarganegaraan (PKn) di SMA Katolik Karitas Tomohon-Sulawesi Utara. Metode yang digunakan dalam penelitian ini adalah metode pendekatan kualitatif dengan pengumpulan data melalui observasi, wawancara dan studi literatur. Penelitian ini menemukan bahwa interaksi guru dan siswa dalam pembelajaran Pendidikan Kewarganegaraan (PKn) di SMA Katolik Karitas Tomohon sudah berjalan dengan baik. Selanjutnya ada hambatan dalam komunikasi antara guru dan siswa dalam proses pembelajaran Pendidikan Kewarganegaraan (PKn) adalah kepribadian dari guru dan siswa. Penelitian ini merekomendasikan penelitian lanjut tentang hal-hal yang mempengaruhi interaksi guru dan siswa dalam proses pembelajaran PKn.

\section{ABSTRACT}

This study aims to describe the teacher's social interactions in learning Civic Education at Catholic High School Karitas Tomohon-North Sulawesi. The method used in this study is a qualitative approach method by collecting data through observation, interviews, and literature studies. This study found that the interaction of teachers and students in learning Civic Education at Karitas Tomohon Catholic High School had gone well. Furthermore, there are obstacles in communication between teachers and students in the learning process of Civic Education is the personality of teachers and lecturers. This study recommends further research on matters that affect the interaction of teachers and students in the learning process of Civic Education.
\end{abstract}

Keywords:

Social interactions

Teacher

Civic Education Learning

\section{Copyright (C) 2019 Theodorus Pangalila}

\section{Pendahuluan}

Banyak persoalan dihadapi dunia pendidikan di Indonesia dewasa ini, mulai dari mutu lulusan yang rendah, kualitas guru, layanan pendidikan, dan lain-lain. Rendahnya kompetensi guru-guru di Indonesia disinyalir menjadi salah satu penyebab rendahnya kualitas pendidikan yang berimbas pada rendahnya mutu sumber daya manusia (siswa) yang lulus dari sekolah-sekolah. Perkembangan masyarakat pada masa modern ini menuntut setiap individu untuk menyesuaikan dengan perubahan yang cepat sebagai salah satu prasyarat untuk memperoleh pengetahuan baru untuk mengembangkan kompetensi dirinya (Aulia \& Arpannudin, 2019). Perkembangan suatu bangsa selalu bergantung pada kualitas sumber daya manusia dengan salah satu indikator kualitas sumber daya manusia adalah pendidikan. Namun jika diperhatikan perkembangan pendidikan di Indonesia belum mencapai tujuan (Lioba Nahak, 2017). Kewarganegaraan dan pembangunan nasional telah terbukti sangat sinergis. Ini berarti tepat untuk mendidik warga negara tentang tanggung jawab kewarganegaraan mereka sebagai cara yang tepat dalam meningkatkan pembangunan.
Kualitas pendidikan 
kewarganegaraan yang dipraktikkan negara sebagian besar menentukan kesopanan dan tingkat perkembangan dan peradaban mungkin terjadi di suatu negara (Enyiaka-J.U, Aminigo-I.M, \& Osaat-S.D, 2018). Dalam kaitan dengan hal ini maka guru dengan kompetensi tingkat tinggi memiliki karakteristik seperti memberikan lebih banyak upaya untuk mengajar, memiliki lebih banyak keinginan dan semangat dalam mengajar dan mampu mengambil keputusan pendidikan yang diperlukan dengan lebih cepat dan lebih (Lonto, Wua, Pangalila, \& Sendouw, 2018).

Dalam kaitan dengan kualitas guru, Sagala (2009, hal. 21) mengartikan guru secara sederhana sebagai "orang yang memberikan ilmu pengetahuan kepada anakanak didik. Karena tugasnya itulah, ia dapat menambah kewibawaan dan keberadaan guru sangat diperlukan masyarakat." Mereka tidak meragukan lagi urgensi guru bagi anak didik dan yakin sepenuhnya bahwa hanya dengan guru lah anak-anak mereka akan tumbuh berkembang, terdidik, pintar dan berkepribadian baik. Pendidikan adalah karya bersama yang berlangsung dalam suatu pola kehidupan insani dan suatu sistem yang dikelompokkan menjadi dua sistem, yakni sistem mekanik dan sistem organik (Sagala, 2009). Sistem mekanik adalah melihat pendidikan sebagai suatu proses yang melibatkan input-process-output yang terdapat hubungan kausal bersifat langsung dan linier. Pandangan ini menunjukkan bahwa intervensi untuk mempengaruhi output dapat didesain dengan memanipulasi input. Sebagaimana diketahui input dalam proses pendidikan mencakup siswa, guru, kurikulum, materi pelajaran, proses pembelajaran, ruang kelas, peralatan, dan kondisi lingkungan. Artinya upaya untuk meningkatkan mutu output dapat dilakukan dengan menambah atau mengurangi kualitas input. Namun praktik dalam proses pembelajaran yang dilakukan guru di kelas selama ini seringkali satu arah dimana siswa hanya mendengarkan apa yang disampaikan guru. Oleh sebab itu siswa perlu lebih dilibatkan secara aktif untuk berinteraksi dengan guru atau antar sesama siswa. Langkah-langkah yang bertujuan mengatasi paradigma pengetahuan krisis telah menyebabkan perlunya perubahan pada sifat manajemen dan memperbarui konten di dalam dunia pendidikan. Di antara alasan-alasan yang menyebabkan krisis pendidikan paradigma tradisional, juga disebut dan fakta bahwa di dunia modern informasi jauh lebih cepat dari pada siklus pembelajaran alami di tingkat sekolah menengah dan tinggi sehingga menghasilkan paradigma tradisional untuk mentransfer pengetahuan dari guru pada sisw menjadi tertinggal dan utopis (Khairutdinova, Kazaeva, \& Czerwinski, 2016).

Kebijakan pendidikan di Indonesia menempatkan Pendidikan Kewarganegaraan sebagai salah satu mata pelajaran yang berfokus pada pembentukan warga negara yang memahami dan mampu melaksanakan hak dan kewajiban mereka untuk menjadi warga negara Indonesia yang cerdas, terampil dan santun seperti yang diamanatkan oleh Pancasila dan UUD 1945 (Komalasari \& Saripudin, 2018). Pendidikan kewarganegaraan harus menjadi perhatian utama karena tidak ada tugas yang lebih penting daripada pengembangan warga negara yang informatif, efektif, dan bertanggung jawab. Demokrasi didukung oleh warga negara yang memiliki pengetahuan, keterampilan, dan disposisi yang diperlukan. Tanpa adanya komitmen yang beralasan dari warga negaranya terhadap nilai-nilai dasar dan prinsip-prinsip demokrasi, masyarakat yang bebas dan terbuka tidak dapat berhasil. Dalam mengejar demokrasi yang lebih sehat dan partisipatif, para sarjana telah lama menetapkan efek positif dari modal sosial, nilai-nilai yang berasal dari sumber daya yang tertanam dalam ikatan sosial dengan orang lain yang menjadi ciri struktur peluang dan tindakan dalam masyarakat (de Zúñiga, Barnidge, \& Scherman, 2017). Oleh karena itu sangat penting bahwa para pendidik, pembuat kebijakan, dan anggota masyarakat sipil membuat kasus dan meminta dukungan pendidikan kewarganegaraan dari semua segmen masyarakat dan dari berbagai lembaga dan pemerintah (Branson, 1998). Tujuan pendidikan kewarganegaraan itu sendiri adalah partisipasi dengan rasa dan tanggung jawab penuh dalam kehidupan politik warga negara yang patuh pada nilai- 
nilai dan prinsip-prinsip dasar demokrasi konstitusional Indonesia (Komara, 2017; Wahab \& Sapriya, 2011).

Menyadari rendahnya kualitas guru-guru yang ada, beberapa tahun terakhir pemerintah mulai menggalakkan program sertifikasi dan uji kompetensi guru. Undang-Undang No. 14 Tahun 2005 tentang Guru dan Dosen dan Permendiknas No. 16 tahun 2007 tentang Standar Kualifikasi Akademik dan Kompetensi Guru menyebutkan bahwa seorang guru dituntut memiliki empat kompetensi yaitu kompetensi pedagogik, kepribadian, sosial, dan profesional. Tujuan program ini adalah menguji kompetensi para guru-guru yang mengajar di sekolah sehingga nantinya bisa disebut guru profesional.

Salah satu kompetensi penting yang kadang dilupakan oleh guru adalah kompetensi sosial. Kompetensi sosial adalah kemampuan guru untuk berkomunikasi dan berinteraksi secara efektif dan efisien dengan siswa, sesama guru, orang tua/wali peserta didik, dan masyarakat. Manusia merupakan makhluk sosial yang tidak dapat hidup tanpa bantuan orang lain. Menurut Sudjarwo (2015, hal. 80), "proses pendidikan sebetulnya adalah wujud dari interaksi antara pendidik dengan peserta didik." Oleh karena itu guru sebagai manusia perlu berinteraksi dengan manusia lainnya (kepala sekolah, guru-guru, siswa, orang tua dan masyarakat sekitar). Interaksi sosial yang menjadi syarat utama terjadinya aktivitas-aktivitas sosial ini merupakan hubungan sosial yang dinamis. Dewasa ini, bahkan interaksi digital rutin dalam kehidupan sehari-hari, dan warga abad ke-21 diharapkan untuk berinteraksi tanpa kendala di ruang digital di mana warga negara muda belajar tentang isu-isu dan berpartisipasi dalam proses demokrasi, ekonomi dan perubahan sosial lainnya (Juliati, Hermawan, \& Firman, 2019). Individu yang tertarik secara sosial dan politik sering menggunakan internet untuk memfasilitasi dan meningkatkan partisipasi sipil dan politik (Kim, Kavanaugh, \& Hult, 2011). Menurut Gillin dan Gillin (Soekanto, 2012, hal. 55), "bentuk umum proses sosial adalah interaksi sosial (yang juga dapat dinamakan proses sosial) karena interaksi sosial merupakan syarat utama terjadinya aktivitas-aktivitas sosial." Bentuk lain proses sosial hanya merupakan bentuk-bentuk khusus dari interaksi sosial. Interaksi sosial merupakan hubungan-hubungan yang dinamis yang menyangkut hubungan antara orangperorangan, antara kelompok manusia, maupun antara orang perorangan dengan kelompok manusia.

Undang-Undang Sistem Pendidikan Nasional Nomor 20 Tahun 2003 pasal 1 ayat 1 menyatakan bahwa tujuan pendidikan nasional adalah: "Pendidikan adalah usaha sadar dan terencana untuk mewujudkan suasana belajar dan proses pembelajaran agar peserta didik secara aktif mengembangkan potensi dirinya untuk memiliki kekuatan spiritual keagamaan, pengendalian diri, kepribadian, kecerdasan, akhlak mulia, serta keterampilan yang diperlukan dirinya, masyarakat, bangsa dan negara." Proses dan penyelenggaraan pendidikan dilakukan secara sadar dan sistematis oleh pendidik dan peserta didik, pemerintah, dan masyarakat luas. Usaha itu berupa kegiatan dan proses yang terjadi dalam hubungan interaktif belajar mengajar antara guru dan siswa yang difasilitasi oleh pemerintah dan didukung oleh masyarakat (Sagala, 2013). Interaksi sosial dalam pendidikan harus memenuhi sejumlah kaidah-kaidah, sehingga peran interaksi sebagai media untuk mencapai kedewasaan paripurna menjadi jelas. Adapun kaidah tersebut meliputi: adanya perencanaan pembelajaran, kurikulum, media pembelajaran dan pelaku interaksi (Sudjarwo, 2015).

Guru Pendidikan Kewarganegaraan tak bisa dimungkiri merupakan bagian tak terpisahkan dari permasalahan yang ada. Kenyataan di lapangan membuktikan bahwa masih banyak guru-guru yang mengajar mata pelajaran PKn di sekolah-sekolah belum memenuhi standar kompetensi yang diharapkan. Masih banyak guru-guru PKn yang belum paham betul bagaimana menunjukkan kompetensi. Kenyataan ini sangat bertentangan dengan kenyataan yang diharapkan. Dalam Undang-Undang No. 14 Tahun 2005 tentang Guru dan Dosen Pasal 1 ayat 1 dikatakan bahwa "Guru adalah 
pendidik profesional dengan tugas utama mendidik, mengajar, membimbing, mengarahkan, melatih, menilai, dan mengevaluasi peserta didik pada pendidikan anak usia dini jalur pendidikan formal, pendidikan dasar, dan pendidikan menengah."

Berdasarkan kenyataan di atas, maka peneliti tertarik untuk melakukan penelitian tentang: Interaksi Sosial Guru dalam Pembelajaran Pendidikan Kewarganegaraan (PKn) di SMA Katolik Karitas TomohonSulawesi Utara.

\section{Metode}

Penelitian ini menggunakan pendekatan kualitatif untuk untuk mengeksplorasi dan memahami makna yang oleh sejumlah individu atau sekelompok orang dianggap berasal dari masalah sosial atau kemanusiaan di SMA Katolik Karitas. Proses penelitian kualitatif ini melibatkan upaya-upaya penting, seperti mengajukan pertanyaan-pertanyaan dan prosedur-prosedur, mengumpulkan data yang spesifik dari para partisipan, menganalisis data secara induktif mulai dari tema-tema yang khusus ke tema-tema umum, dan menafsirkan makna dan data.

Untuk memperoleh data yang benarbenar holistik tentang topik yang diteliti, maka dalam penelitian ini, peneliti terlibat secara langsung di situs penelitian lewat wawancara dan observasi secara langsung kepada siswa, guru PPKn, orang tua dan kepala sekolah. Penelitian ini dilaksanakan di Sekolah Menengah Atas (SMA) Katolik Karitas Tomohon-Sulawesi Utara. Instrumen yang digunakan dalam pengumpulan data untuk menjawab permasalahan penelitian ini adalah menggunakan instrumen utama adalah peneliti sendiri dengan menggunakan teknik berfikir analis untuk mampu membuat/menarik kesimpulan/verifikasi terhadap fenomena yang diteliti dan instrumen bantu adalah sarana-sarana atau alat-alat yang dapa membantu penelitian dalam menarik kesimpulan atau membuat verifikasi terhadap fenomena yang diteliti.

Teknik analisis data yang digunakan dalam penelitian ini mengikuti Miles dan Huberman, yang terdiri dari empat alur kegiatan yang terjadi secara bersamaan, yaitu reduksi data, penyajian data, dan penarikan kesimpulan. Berikut ini adalah keterkaitan antar komponen-komponen analisis data. Di dalam pengujian keabsahan data, maka peneliti akan menggunakan validitas internal (credibility) pada aspek nilai kebenaran, pada penerapannya ditinjau dari validitas eksternal (transferability), dan reliabilitas (dependability) pada aspek konsistensi, serta objektivitas (confirmability) pada aspek naturalis (Sugiyono, 2011). Pada penelitian kualitatif, tingkat keabsahan lebih ditekankan pada data yang diperoleh. Melihat hal tersebut maka kepercayaan data hasil penelitian dapat dikatakan memiliki pengaruh signifikan terhadap keberhasilan sebuah penelitian. Data yang valid dapat diperoleh dengan melakukan uji kredibilitas (validitas internal) terhadap data hasil penelitian sesuai dengan prosedur uji kredibilitas data dalam penelitian kualitatif.

\section{Hasil dan Pembahasan}

Peran pendidikan kewarganegaraan secara substantif tidak saja mendidik generasi muda menjadi warga negara yang cerdas dan sadar akan hak dan kewajibannya dalam konteks kehidupan bermasyarakat, berbangsa, dan bernegara yang merupakan penekanan dalam istilah pendidikan kewarganegaraan, melainkan juga membangun kesiapan warga negara untuk menjadi warga dunia (global society) (Aulia \& Arpannudin, 2019). Dalam Undang-Undang No. 14 Tahun 2005 tentang Guru dan Dosen salah satu kompetensi yang harus dimiliki oleh guru adalah kompetensi sosial. Kompetensi sosial guru berkaitan dengan kemampuan seorang guru dalam membangun komunikasi dan interaksi yang baik dan efektif dengan sekolah maupun lingkungan di luar sekolah (orang tua siswa). Kompetensi dapat digambarkan sebagai kemampuan untuk melaksanakan satu tugas, peran atau tugas, kemampuan mengintegrasikan pengetahuan, keterampilan, sikap, nilai pribadi, dan kemampuan untuk membangun pengetahuan dan keterampilan yang didasarkan pada pengalaman dan pembelajaran yang dilakukan untuk tujuan pribadinya (Costa, Roe, \& Taillieu, 2001; Hukkelberg \& Ogden, 2019).

Kompetensi sosial guru merupakan kemampuan guru untuk berkomunikasi dan 
berinteraksi secara harmonis dengan peserta didik, sesama pendidik, tenaga kependidikan, orang tua/wali peserta didik, dan masyarakat sekitar (Lonto et al., 2018). Indikasinya guru mampu berkomunikasi dan bergaul secara harmonis dengan peserta didik, sesama pendidik, dan dengan tenaga kependidikan, serta dengan orang tua/wali peserta didik dan masyarakat sekitar. Menurut Goleman (2006, hal. 30), "kecerdasan atau kompetensi sosial merupakan rujukan tepat bagi kecerdasan yang tak hanya tentang relasi kita dengan orang lain namun dalam relasi itu."

Interaksi sosial antara guru PKn dan siswa dalam proses pembelajaran di SMA Katolik Karitas sudah berjalan dengan baik. Dalam Undang-Undang No. 14 Tahun 2005 tentang Guru dan Dosen salah satu kompetensi yang harus dimiliki oleh guru adalah kompetensi sosial. Kompetensi sosial guru berkaitan dengan kemampuan seorang guru dalam membangun komunikasi dan interaksi yang baik dan efektif dengan sekolah maupun lingkungan di luar sekolah (orang tua siswa). Dalam Undang-Undang No. 20 Tahun 2003 tentang Sistem Pendidikan Nasional pasal 1 ayat 19 sudah dikatakan pula bahwa pembelajaran adalah "proses interaksi peserta didik dengan pendidik dan sumber belajar pada suatu lingkungan belajar." Berkaitan dengan interaksi guru PKn dalam proses pembelajaran di SMA Katolilk Karitas Tomohon, interaksi guru PKn dengan para siswa berjalan dengan baik. Guru PKn di SMA tersebut komunikatif dan mudah bergaul dengan para siswa. Hal ini terlihat ketika pembelajaran di dalam kelas dan dalam kegiatan-kegiatan ekstrakurikuler lainnya. Dai perspektif siswa, guru PKn sangat baik dan suka bergaul dengan siswa, tegas, serius, akan tetapi mampu berkomunikasi dengan baik dengan siswa. Dalam proses pembelajaran guru PKn menggunakan modelmodel pembelajaran yang interaktif dan menarik bagi kami. Guru PKn mengajar sangat jelas dan komunikatif. Ada saat dia serius, akan tetapi pada saat tertentu mencairkan suasana dengan kami. Dalam pembelajaran PKn semua siswa terlibat aktif sehingga pembelajaran menyenangkan bagi seluruh siswa di dalam kelas.

Penggunaan model-model pembelajaran yang aktif, kreatif dan inovatif membantu siswa dan guru untuk berinteraksi dan berkomunikasi dengan baik. Menurut Supardan (2011, hal. 140), "interaksi sosial adalah proses sosial yang menyangkut hubungan timbal balik antarpribadi, kelompok, maupun pribadi dengan kelompok. Interaksi sosial tersebut merupakan syarat utama terjadinya aktivitas-aktivitas sosial". Menurut Gillin dan Gillin (Soekanto, 2012, hal. 55), "bentuk umum proses sosial adalah interaksi sosial (yang juga dapat dinamakan proses sosial) karena interaksi sosial merupakan syarat utama terjadinya aktivitasaktivitas sosial." Bentuk lain proses sosial hanya merupakan bentuk-bentuk khusus dari interaksi sosial. Interaksi sosial merupakan hubungan-hubungan yang dinamis yang menyangkut hubungan antara orang-orangperorangan, antara kelompok-kelompok manusia, maupun antara orang perorangan dengan kelompok manusia. Interaksi sosial tersebut merupakan syarat utama terjadinya aktivitas-aktivitas sosial. Dalam proses pembelajaran antara pendidik dan peserta didik harus ada interaksi. Pendidikan pada dasarnya merupakan interaksi antara pendidik (guru) dengan peserta didik (siswa), untuk mencapai tujuan pendidikan, yang berlangsung dalam lingkungan tertentu (Inah, 2015). Dalam hal ini, interaksi sosial guru dalam pembelajaran PKn di sekolah tampak jelas dalam interaksinya yang baik dengan siswa, sesama guru, kepala sekolah dan orang tua siswa.

Sementara itu secara lebih rinci dalam Permendiknas No. 16 tahun 2007 tentang "Standar Kualifikasi Akademik dan Kompetensi Guru disebutkan bahwa kompetensi guru mata pelajaran PKn pada SMP/MTs, SMA/MA, SMK/MAK adalah sebagai berikut:

- Memahami materi, struktur, konsep, dan pola pikir keilmuan yang mendukung mata pelajaran Pendidikan Kewarganegaraan.

- Memahami substansi Pendidikan Kewarganegaraan yang meliputi 
pengetahuan kewarganegaraan (civic knowledge), nilai dan sikap kewarganegaraan (civic disposition), dan keterampilan kewarganegaraan (civic skills).

- Menunjukkan manfaat mata pelajaran pendidikan kewarganegaraan.

Pada dasarnya, terdapat berbagai faktor yang mempengaruhi keberhasilan pendidikan, antara lain: guru, siswa, sarana dan prasarana, lingkungan pendidikan, kurikulum. Dari beberapa faktor tersebut, guru dalam kegiatan proses pembelajaran di sekolah menempati kedudukan yang sangat penting dan tan- pa mengabaikan faktor penunjang yang lain, guru sebagai subjek pendidikan sangat menentukan keberhasilan pendidikan itu sendiri (Widoyoko \& Rinawati, 2012). Dalam interaksi guru-siswa dalam proses belajar mengajar, terdapat beberapa komponenkomponen, yaitu : (1) interaksi bersifat edukatif; (2) dalam interaksi terjadi perubahan tingkah laku pada siswa sebagai hasil belajar mengajar; (3) peranan dan kedudukan guru yang tepat dalam proses interaksi belajar mengajar; (4) interaksi sebagai proses belajar mengajar; (5) sarana kegiatan proses belajar mengajar yang tersedia, yang membantu tercapainya interaksi belajar mengajar secara efektif dan efisien (Roestiyah, 1989).

\section{Faktor-Faktor yang Menghambat Interaksi Sosial Guru Pendidikan Kewarganegaraan Di SMA Katolik Karitas Tomohon}

Tak bisa dimungkiri bahwa tujuan paling pertama dan terutama dari Pendidikan Kewarganegaraan adalah menjadikan warga negara suatu bangsa menjadi baik (to be good and smart citizens). Dalam pembelajaran PKn interaksi antara guru dan siswa merupakan dua aspek yang tidak bisa terpisahkan. Kendati demikian dalam hasil penelitian diperoleh bahwa dalam proses pembelajaran PKn di sekolah terdapat hambatan yang ditemui oleh guru dalam berinteraksi dengan siswa. Kendati guru sudah berusaha berinteraksi dan berkomunikasi dengan baik dengan para siswa, tetap saja ada siswa yang kurang atau tidak aktif. Berkaitan dengan hal ini Mulyasa (2007, hal. 17) mengatakan bahwa "pengelolaan kelas merupakan keterampilan pembelajar untuk menciptakan iklim pembelajaran yang kondusif, dan mengendalikannya jika terjadi gangguan dalam proses pembelajaran." Dalam proses pembelajaran beberapa prinsip yang harus diperhatikan dalam pengelolaan kelas adalah (1) kehangatan dan antusiasme (2) tantangan, (3) bervariasi, (4) luwes, (5) penekanan pada hal-hal positif, dan (6) penanaman disiplin diri. Perencanaan pembelajaran sebagai scenario untuk menggelar interaksi sosial antara peserta didik dengan pendidik; merupakan alur yang harus dilalui atau dikembangkan pada saat interaksi berlangsung. Perencanaan pembelajaran inilah yang sangat membedakan secara esensial, proses pembelajaran dengan interaksi sosial lainnya (Sudjarwo, 2015, hal. 80).

Faktor lain yang menghambat interaksi guru dan siswa dalam proses pembelajaran PKn di SMA Katolik Karitas Tomohon adalah kepribadian guru dan siswa. Siswa yang memiliki kepribadian terbuka akan dengan mudah menjalin hubungan interaksi dengan guru dalam proses pembelajaran. Sebaliknya guru yang memiliki kepribadian tertutup akan sulit untuk berinteraksi dengan siswa dalam proses pembelajaran. Sama halnya juga dengan siswa yang memiliki kepribadian terbuka akan dengan mudah berinteraksi dengan guru, tetapi yang kepribadiannya tertutup, seaktif apapun guru PKn dalam mengajar tidak akan mudah untuk menimbulkan aksi dari siswa yang bersangkutan.

Pendidikan Kewarganegaraan merupakan salah satu bidang kajian yang mengemban misi nasional untuk mencerdaskan kehidupan bangsa Indonesia melalui koridor "value-based education" (Budimansyah \& Suryadi, 2008). Konfigurasi atau kerangka sistematik PKn dibangun atas dasar paradigma yakni pertama, PKn secara kurikuler dirancang sebagai subjek pembelajaran yang bertujuan untuk mengembangkan potensi individu agar menjadi warga negara Indonesia yang berakhlak mulai, cerdas, partisipatif, dan bertanggung jawab. Kedua, PKn secara teoretis dirancang sebagai subjek 
pembelajaran yang memuat dimensi-dimensi kognitif, afektif, dan psikomotorik yang bersifat konfluens atau saling berpenetrasi dan terintegrasi dalam konteks substansi ide, nilai, konsep, dan moral Pancasila, kewarganegaraan yang demokratis, dan bela negara. Ketiga, PKn secara programatik dirancang sebagai subjek pembelajaran yang menekankan pada isi yang mengusung nilainilai (content embedding values) dan pengalaman belajar (learning experience) dalam bentuk berbagai perilaku yang perlu diwujudkan dalam kehidupan sehari-hari dan merupakan tuntutan hidup bagi warga negara dalam kehidupan bermasyarakat, berbangsa, dan bernegara sebagai penjabaran lebih lanjut dari ide, nilai, konsep, dan moral Pancasila, kewarganegaraan yang demokratis, dan bela negara (Pangalila, 2017).

\section{Simpulan}

Interaksi guru dan siswa dalam proses pembelajaran Pendidikan Kewarganegaraan (PKn) di SMA Katolik Karitas sudah berjalan dengan baik. Interaksi sosial guru dalam pembelajaran PKn di sekolah tampak jelas dalam interaksinya yang baik dengan siswa, sesama guru, kepala sekolah dan orang tua siswa. Dalam pembelajaran PKn interaksi antara guru dan siswa merupakan dua aspek yang tidak bisa terpisahkan. Kendati demikian dalam hasil penelitian diperoleh bahwa dalam proses pembelajaran PKn di sekolah terdapat hambatan yang ditemui oleh guru dalam berinteraksi dengan siswa. Interaksi guru dan siswa dalam proses pembelajaran Pendidikan Kewarganegaraan (PKn) di SMA Katolik Karitas Tomohon dipengaruhi oleh faktor kepribadian guru dan siswa.

\section{Ucapan Terima Kasih}

Terima kasih diucapkan kepada Rektor Universitas Negeri Manado dan Ketua LPPM Universitas Negeri Manado yang telah memfasilitasi penelitian ini.

\section{Referensi}

Aulia, S. S., \& Arpannudin, I. (2019). Pendidikan kewarganegaraan dalam lingkup sosio- kultural pendidikan nonformal. Jurnal Civic Education, 3(1), 112.

Branson, M. S. (1998). The role of civic education: a forthcoming education policy task force position paper from the communitarian network. Center for Civic Education.

Budimansyah, D., \& Suryadi, K. (2008). PKN dan masyarakat multikultural. Bandung: Program Studi Pendidikan Kewarganegaraan Sekolah Pascasarjana Universitas Pendidikan Indonesia.

Costa, A. C., Roe, R. A., \& Taillieu, T. (2001). Trust within teams: the relation with performance effectiveness. European journal of work and organizational psychology, 10(3), 225-244.

de Zúñiga, H. G., Barnidge, M., \& Scherman, A. (2017). Social media social capital, offline social capital, and citizenship: Exploring asymmetrical social capital effects. Political Communication, 34(1), 44-68.

https://doi.org/10.1080/10584609.2016. 1227000

Enyiaka-J.U, Aminigo-I.M, \& Osaat-S.D. (2018). Basis of civic education in the philosophy of Aristotle: a Nigerian reflection. International Journal of Research \& Review, 5(May), 256-268.

Goleman, D. (2006). Social intelligence. New York: Random House LLC.

Hukkelberg, S., \& Ogden, T. (2019). What is social competence? An investigation into the concept among children with antisocial behaviours. Emotional and Behavioural Difficulties, 00(00), 1-14. https://doi.org/10.1080/13632752.2019. 1687168

Inah, E. N. (2015). Peran komunikasi dalam interaksi guru dan siswa. Jurnal AlTa'dib, 8(2), 150-167.

Juliati, Hermawan, W., \& Firman, M. (2019). Pendidikan kewarganegaraan sebagai wahana untuk meningkatkan kesadaran hidup yang lebih baik di era global. Jurnal Civics: Media Kajian Kewarganegaraan, 16(1), 29-37. Diambil dari https://journal.uny.ac.id/index.php/civic s/article/view/23340/pdf

Khairutdinova, R. R., Kazaeva, E. A., \& Czerwinski, G. (2016). The use of the task method in civic education of 
students. International Journal of Environmental and Science Education, 11(3), 245-259. https://doi.org/10.12973/ijese.2016.308a Kim, B. J., Kavanaugh, A. L., \& Hult, K. M. (2011). Civic engagement and internet use in local governance: hierarchial linear models for understanding the role of local community groups. Administration \& Society, 43(7), 807835.

https://doi.org/10.1177/0095399711413 873

Komalasari, K., \& Saripudin, D. (2018). The influence of living values educationbased civic education textbook on student's character formation. International Journal of Instruction, 11(1), 395-410. https://doi.org/10.12973/iji.2018.11127a

Komara, E. (2017). Curriculum and civic education teaching in Indonesia. International Journal for Educational Studies, 10(1), 23-32.

Lioba Nahak, R. (2017). The differences of students' learning motivation in learning Civic Education using democratic learning model and conventional learning model in grade $\mathrm{V}$ of $\mathrm{SD}$ Bertingkat Kelapa Lima 3, Kupang. PEOPLE: International Journal of Social Sciences, 3(1), 357-370. https://doi.org/10.20319/pijss.2017.31.3 57370

Lonto, A. L., Wua, T. D., Pangalila, T., \& Sendouw, R. (2018). Moral work, teaching profession and character education in Forming Students' Characters. International Journal of Engineering and Technology(UAE), 7(4).

https://doi.org/10.14419/ijet.v7i4.28.225 60

Mulyasa, E. (2007). Kurikulum Tingkat Satuan Pendidikan (KTSP). Bandung: Rosdakarya.

Pangalila, T. (2017). Peningkatan civic disposition siswa melalui pembelajaran Pendidikan Kewarganegaraan (PKn). Jurnal Pendidikan Kewarganegaraan
Unlam, 7(1), 91-103.

Roestiyah. (1989). Masalah-masalah ilmu keguruan. Jakarta: Bina Aksara.

Sagala, S. (2009). Kemampuan profesional guru dan tenaga kependidikan. Bandung: Alfabeta. Diambil dari https://books.google.co.id/books?id=AE SOAQAAMAAJ

Sagala, S. (2013). Manajemen strategik dalam peningkatan mutu pendidikan. Bandung: Alfabeta.

Soekanto, S. (2012). Sosiologi suatu pengantar. Jakarta: Raja Grafindo Persada.

Sudjarwo. (2015). Proses sosial dan interaksi sosial dalam pendidikan. Bandung: Mandar Maju.

Supardan, D. (2011). Pengantar ilmu sosial: sebuah kajian pendekatan struktural. Jakarta: Bumi Aksara.

Wahab, A. A., \& Sapriya. (2011). Teori dan landasan pendidikan kewarganegaraan. Bandung: Alfabeta.

Widoyoko, S. E. P., \& Rinawati, A. (2012). Pengaruh kinerja guru terhadap motivasi belajar siswa di SMP Muhammadiyah Purworejo. Jurnal Cakrawala Pendidikan, 2(2), 278-289. 